\title{
ZINC FERTILIZATION EFFECTS ON SEED CADMIUM ACCUMULATION IN OILSEED AND GRAIN CROPS GROWN ON NORTH DAKOTA SOILS
}

\author{
Gonzalo A. Rojas-Cifuentes ${ }^{1 *}$, Burton L. Johnson' ${ }^{1}$, Marisol T. Berti ${ }^{1}$, and Wendell A. Norvell ${ }^{2}$
}

\begin{abstract}
The Cd concentration in the seed of crops depends on various soil factors including parent material, texture, $\mathrm{pH}$, soil redox, and salinity. Cadmium accumulation also varies among crop species and cultivars within a species. Cadmium and $\mathrm{Zn}$ may have either an antagonistic or a synergistic effect on plant uptake that can be influenced by the soil $\mathrm{Cd}$ and $\mathrm{Zn}$ concentrations. The objective was to determine the effect of $\mathrm{Zn}$ fertilizer additions on the seed Cd of nine crops commonly grown in North Dakota, USA. Studies were conducted at five North Dakota locations representing different soil series during 1994 and 1995. In Experiment 1, nine crops common in North Dakota were grown with and without the addition of $25 \mathrm{~kg} \mathrm{ha}^{-1} \mathrm{Zn}$ fertilizer. Among crops evaluated, the greatest seed Cd accumulation occurred in flax (Linum usitatissimum L.) followed by sunflower (Helianthus annuus L.), soybean (Glycine max [L.] Merr.), and durum wheat (Triticum turgidum L. var. durum). In Experiment 2, two durum wheats and one flax cultivar were grown under three Zn treatments of 0, 5, and $25 \mathrm{~kg} \mathrm{ha}^{-1}$. In Experiment again flax had the higher seed Cd level compared with the two durum varieties. Based on the results from both studies, addition of $\mathrm{Zn}$ fertilizer did not consistently reduce seed Cd content, and even when statistically significant, the level of reduction was small and not likely to impact marketability of Cd accumulating crops such as flax, sunflower, soybean, and durum.
\end{abstract}

Key words: Soil series, seed, uptake, nutrients, contamination, Linum usitatissimum, Triticum turgidum.

$\mathrm{C}$ admium is a non-essential microelement that can accumulate in seeds of edible plants at levels that exceed acceptable limits for human consumption (Gerritse et al., 1983; Hocking and McLaughlin, 2000). The daily adult human limit for Cd intake has been set at $70 \mu \mathrm{g}$ by the World Health Organization and the U.S. Department of Health (Chaney et al., 1993). Increasing international concerns about the risks associated with long-term consumption of crops containing elevated $\mathrm{Cd}$ levels (McLaughlin et al., 1994) has led the international food standards organization, Codex Alimentarius Commission, to propose a $200 \mathrm{~g} \mathrm{Cd} \mathrm{kg}^{-1}$ limit for cereals, pulses, oilseeds, and legumes and $400 \mathrm{~g} \mathrm{Cd} \mathrm{kg}^{-1}$ for rice (Oryza sativa L.) in Europe (Codex Alimentarius Commission, 2000). Vegetables contribute more than $70 \%$ of the Cd intake in human diets. Dietary intake of $\mathrm{Cd}$ depends on both the amount of food consumed and the $\mathrm{Cd}$ concentration in the consumed food (Wagner, 1993). High Cd intake by humans has been associated with renal tubular dysfunction and osteoporosis. Renal

${ }^{1}$ North Dakota State University, Department of Plant Sciences. P.O. Box 6050, Fargo, North Dakota 58108-6050, USA.

*Corresponding author (gonzalo.rojas@ndsu.edu).

${ }^{2}$ USDA/ARS Plant, Soil, and Nutrition Laboratory, Ithaca, New York, USA.

Received: 13 June 2011.

Accepted: 3 January 2012. tubular problems are the main health hazard associated with moderately high Cd consumption in foods (Wagner, 1993).

Two major soil factors that influence $\mathrm{Cd}$ levels in plants are soil Cd concentration and soil pH (Lagerwerff, 1971; Haghiri, 1973; Bingham, 1979; McLaughlin et al., 1994). Plants tend to accumulate higher amounts of $\mathrm{Cd}$ when grown on soils with higher concentrations of $\mathrm{Cd}$. Brennan and Bolland (2004) reported that soil test Cd was highly correlated with grain $\mathrm{Cd}$ in both wheat (Triticum aestivum L.) and canola (Brassica napus L.). Cadmium uptake by plants decreases as the soil $\mathrm{pH}$ increases. Cadmium uptake can also be influenced to a lesser extent by soil redox potential, soil type and series, salinity, cation exchange capacity, presence of competitive metals (i.e., Zn), microbial activity, plant species, and cultivar (Wagner, 1993). McLaughlin et al. (1994) noted that both irrigation water quality and climate influence $\mathrm{Cd}$ uptake by plants. Chloride is very important in $\mathrm{Cd}$ uptake by crops, especially in calcareous soils in which uptake would normally be limited by high $\mathrm{pH}$ (Li et al., 1997; Norvell et al., 2000; Wu et al., 2002; Makino et al., 2006).

Cadmium accumulation and distribution within plants varies among species and cultivars (John, 1973; Jarvis et al., 1976; Bingham, 1979; Kuboi et al., 1987; Wagner, 1993; Jalil et al., 1994). Plants usually exhibit characteristics of $\mathrm{Cd}$ accumulation inherent to their 
families (Brennan and French, 2005). Plants may accumulate $\mathrm{Cd}$ in different plant tissues such as stems, leaves, roots, or seed. Carrier et al. (2003) reported that canola plants accumulated high amounts of $\mathrm{Cd}$ in roots and stems. Tobacco (Nicotiana tabacum L.) (Ryan et al., 1982) and soybean (Davis, 1984) plants accumulate Cd in the leaves rather than the roots. Simon (1998) studied the $\mathrm{Cd}$ accumulation in sunflower and found that $\mathrm{Cd}$ was accumulated in roots, shoots, leaves, and seeds. The high $\mathrm{Cd}$ levels in durum wheat seed is due to the elevated remobilization of $\mathrm{Cd}$ from the leaves to maturing grains during seed filling (Harris and Taylor, 2001). Brennan and French (2005) found that yellow lupin (Lupinus luteus L.) had $\mathrm{Cd}$ concentrations three times higher in drier shoots and nine times higher in grain than narrowed-leafed lupin (Lupinus angustifolius L.).

The relationship between $\mathrm{Cd}$ and $\mathrm{Zn}$ in plants pertaining to uptake, translocation, and remobilization of these ions is very complex. Both antagonist and synergistic Cd$\mathrm{Zn}$ interactions have been reported (Bingham, 1979). Geochemically, $\mathrm{Zn}$ and $\mathrm{Cd}$ are chacophilic in character and are expected to mimic their uptake by plants (Alloway, 1995). Cadmium and $\mathrm{Zn}$ have similar ionic structures and electronegativities; however, they have different ionic radii $\left(\mathrm{Zn}^{2+}=0.074 \mathrm{~nm}, \mathrm{Cd}^{2+}=0.097 \mathrm{~nm}\right)$. These differences could be comparatively related to plant selectivity (Abdel-Sabour et al., 1988). The reduction in $\mathrm{Cd}$ uptake caused by $\mathrm{Zn}$ fertilization might result from the competitive transport and absorption interaction between these two ions (Moustakas et al., 2011).

The Cd content of soils is predominately a function of the soil parent material. Levels of Cd are typically high in soils formed from marine shales, whereas soils low in $\mathrm{Cd}$ were formed from granitic parent materials. The major source of $\mathrm{Cd}$ in North Dakota soils is from mineralization of marine shales of the Cretaceous period that contain high levels of $\mathrm{Cd}$ in Pierre Shales (Schultz et al., 1980). Soils low in Cd are reported to vary from 0.01 to $30 \mu \mathrm{g} \mathrm{Cd} \mathrm{g}{ }^{-1}$; however, a more typical range in Cd content is 0.06 to $0.5 \mu \mathrm{g} \mathrm{g}^{-1}$ (Haghiri, 1974; Wagner, 1993). Environmental contamination of soils with $\mathrm{Cd}$ is often associated with mines, smelters, and the manufacturing of $\mathrm{Ni}-\mathrm{Cd}$ batteries or Cd-based pigments. Industrial wastes or sewage sludges contaminated with $\mathrm{Cd}$ also are major sources of soil contamination. Another source of $\mathrm{Cd}$ contamination is the long-term use of naturally Cd-rich phosphate fertilizers. Phosphate fertilizers produced from rock phosphates may retain $\mathrm{Cd}$ in amounts ranging from 5 to $400 \mathrm{mg} \mathrm{kg}^{-1}$ (Williams and David, 1976; Choudhary et al., 1994). US products on sale today include certain western US phosphate products with $250 \mathrm{mg} \mathrm{Cd} \mathrm{kg}^{-1}$.

Zinc $\left(\mathrm{ZnSO}_{4}\right)$ has been reported to have either an antagonistic (Abdel-Sabour et al., 1988) or a synergistic effect on Cd uptake (Williams and David, 1976). Haghiri (1974) reported that applying $\mathrm{Zn}$ to soil, reduced $\mathrm{Cd}$ uptake in soybean, but did not appear to be practical since the suppression of Cd occurred only when large amounts of $\mathrm{Zn}$ fertilizer were added. Based on field studies conducted in North Dakota in 1989 and 1990, Chaney et al. (1993) reported that application of $\mathrm{Zn}$ fertilizer did not significantly reduce $\mathrm{Cd}$ concentration in sunflower kernels from plants grown on soil series that were naturally high in Cd. Conversely, Oliver et al. (1994) reported that $\mathrm{Cd}$ concentration in durum wheat seed may decrease by up to $50 \%$ from the addition of 2.5 to $5 \mathrm{~kg}$ $\mathrm{Zn} \mathrm{ha}{ }^{-1}$ for soils that are deficient in $\mathrm{Zn}$. Harris and Taylor (2001) suggested that inhibition of $\mathrm{Cd}$ accumulation of durum wheat seeds by $\mathrm{Zn}$ may be confined to conditions where applications of $\mathrm{Zn}$ alleviate $\mathrm{Zn}$ stress. These studies suggest that the $\mathrm{Zn}$ status of the soil may have a major influence on the effect of $\mathrm{Zn}$ fertilization on $\mathrm{Cd}$ uptake by crops. Chen et al. (2007) determined that $\mathrm{Cd}$ accumulation in barley (Hordeum vulgare L.) grains increased with external $\mathrm{Cd}$ levels at the time of exposure and is remobilized from other plant parts suggesting that awn, rachis, and glume may be involved in $\mathrm{Cd}$ transport into developing grains.

The objectives of these studies were to determine the effect of added $\mathrm{Zn}$ fertilizer on the $\mathrm{Cd}$ accumulation in the seed of several crops grown on different extensive soil series in North Dakota, and to compare the accumulation of seed Cd by commercial crops commonly grown in North Dakota.

\section{MATERIALS AND METHODS}

\section{Experimental locations and soil characteristics}

Two separate experiments were conducted during the 1994 and 1995 growing seasons at several North Dakota locations representative of five soil series. Studies were located at Minot (48 $10^{\prime} 5^{\prime}$ ' N, 101 17'4" W; 48 $10^{\circ} 5^{\prime}$ ', N, 101 19 '00' W) (Howey, 1974) in north central North Dakota, and at Langdon, in northeastern North Dakota $\left(48^{\circ} 46^{\prime} 18^{\prime \prime} \mathrm{N}, 98^{\circ} 22^{\prime} 30^{\prime \prime} \mathrm{W}\right)$ on soils of glacial till parent material (Simmons, 1990). In eastern North Dakota, studies were conducted at Prosper (46 59'00', N, 97 $\left.50^{\prime} 31^{\prime \prime} \mathrm{W}\right)$ on a complex of two soil series and at Fargo (46 $55^{\prime} 00$ " N, 96 48'00" W) on soils of lacustrine origin (USDA Soil Conservation Service, 1985).

Locations, parent material, soil series, and soil taxonomy are shown in Table 1. The Niobell and Williams soil series were identified at the Minot location. At Langdon, the soil series was Svea. The Prosper Experiment was established on a complex of Bearden and Perella soil series. At Fargo, the soil series was Fargo (Soil Survey Division, 2001). Soil diethylenetriaminepentaacetic (DTPA)-extractable $\mathrm{Zn}$ and $\mathrm{Cd}$ concentration, and soil $\mathrm{pH}$ for each soil series are shown in Table 2.

\section{Experiment 1}

The objective of Experiment 1 was to determine the 
Table 1. Location, parent material, soil series, and soil taxonomy for Experiment 1 and Experiment 2.

\begin{tabular}{|c|c|c|c|}
\hline Location & $\begin{array}{l}\text { Parent } \\
\text { material }\end{array}$ & Soil series ${ }^{1}$ & Soil taxonomy ${ }^{1}$ \\
\hline Fargo & Lacustrine & Fargo & Fine, smectitic, frigid Typic Epiaquerts \\
\hline Minot & Glacial till & Niobell & Fine, smectitic, frigid Glossic Natrustolls \\
\hline Minot & Glacial till & Williams & $\begin{array}{l}\text { Fine-loamy, mixed, superactive, frigid } \\
\text { Typic Arugiustolls }\end{array}$ \\
\hline Langdon & Glacial till & Svea & $\begin{array}{l}\text { Fine-loamy, mixed, superactive, frigid } \\
\text { Pachic Hapludolls }\end{array}$ \\
\hline Prosper & Lacustrine & $\begin{array}{l}\text { Complex of } \\
\text { Bearden and } \\
\text { Perella }\end{array}$ & $\begin{array}{l}\text { Fine-silty, mixed, superactive frigid, } \\
\text { Aeric Calciaquolls } \\
\text { Fine-silty, mixed, superactive, frigid, } \\
\text { Typic Endoaquolls }\end{array}$ \\
\hline
\end{tabular}

${ }^{1}$ Source: Web Soil Survey (http://websoilsurvey.nrcs.usda.gov/app/HomePage.htm).

Table 2. Mean soil $\mathrm{Zn}$ and Cd content, and soil pH at five North Dakota locations from 0 to $50 \mathrm{~cm}$ deep.

\begin{tabular}{llcc}
\hline Location (series) & \multicolumn{1}{c}{ Soil Zn } & Soil Cd & Soil pH \\
\cline { 2 - 3 } Fargo (Fargo) & 0.96 (high) & \\
Langdon (Seva) & 1.55 (very high) & 0.10 & 7.22 \\
Minot (Williams) & 0.62 (medium) & 0.08 & 7.59 \\
Minot (Niobell) & 0.97 (high) & 0.16 & 6.50 \\
Prosper (Bearden/Perella) & 0.60 (medium) & 0.22 & 7.88 \\
\hline
\end{tabular}

effect of applied $\mathrm{Zn}$ fertilizer on the seed Cd content of several major crops grown in North Dakota. 'Renville' durum wheat, 'Grandin' hard red spring wheat, 'Robust' and 'Stark' barley (6- and 2-rowed type, respectively), 'Whitestone' oat (Avena sativa L.), 'Omega' flax, nonoilseed sunflower hybrid '954', corn hybrid '2442' (Zea mays L.), 'McCall' soybean, and two dry edible bean (Phaseolus vulgaris L.) cultivars 'Olathe', a Pinto type ,and 'Norstar', a navy type; were established on each soil series during the 1994 and 1995 growing seasons.

The experimental design was a randomized complete block with three replicates in a split-plot arrangement (Steel and Torrie, 1980). Crops constituted the main plot, while two levels of $\mathrm{Zn}, 0$ and $25 \mathrm{~kg} \mathrm{ha}^{-1}$, added as $\mathrm{ZnSO}_{4}$ dry granular fertilizer, constituted the subplot. The cereal grains and flax were sown in six rows spaced $0.31-\mathrm{m}$ apart, while the row crops (sunflower, corn, soybean, and dry beans) were sown in three rows spaced 0.76-m apart. The Experiment was established using conventional plot research equipment and following recommended production practices for each crop. Plots were 6.1-m long and $2-\mathrm{m}$ wide. The $\mathrm{Zn}$ fertilizer $\left(\mathrm{ZnSO}_{4}\right)$ was broadcast prior to planting and then incorporated by disking (5to $10-\mathrm{cm}$ depth). Soil samples for mean $\mathrm{Cd}, \mathrm{Zn}$, and $\mathrm{pH}$ determination were taken prior to seeding and $\mathrm{Zn}$ fertilization from three soil cores within each replicate. Each soil core consisted of two fractions, one from the surface to a depth of $15 \mathrm{~cm}$, and the other from a depth of 30 to $51 \mathrm{~cm}$.

During the 1994 growing season, the studies at Minot (Niobell and Williams soil series) and Langdon were lost because of improper harvesting. The Minot Niobell-site data from the 1995 growing season were not useable because the trial was severely damaged by wildlife. Therefore, Experiment 1 had six environments: Fargo 94,
Prosper 94, Fargo 95, Langdon 95, Minot (Williams) 95, and Prosper 95.

For Cd determination of the small grains, 100 spikes were hand harvested at random from the four center plot rows. Cadmium determinations in soybean and dry edible bean were from 100 hand-harvested pods from plants in the center plot row. Six sunflower heads and six corn ears were taken from the center plot row and 100 flax bolls were harvested from the four center plot rows for Cd determination. Dry edible bean, soybean, sunflower, and corn were hand threshed, and sunflower seed was dehulled using a forced-air dehuller. Cereal grains for $\mathrm{Cd}$ determination were threshed in a thresher constructed with non-galvanized metal. Flax bolls were placed in cloth bags and threshed by passing them between rotating rubber-coated rollers. The straw was removed by hand and the remaining sample aspirated to remove the chaff. Great care was taken to prevent seed $\mathrm{Cd}$ contamination during harvest and seed cleaning operations.

\section{Experiment 2}

In Experiment 2, the effect of $\mathrm{Zn}$ fertilizer on the $\mathrm{Cd}$ seed content of two durum cultivars, Renville and Medora, and the flax cultivar, Omega, was determined. 'Medora' has been reported to be a high Cd accumulator (Choudhary et al., 1994; Jalil et al., 1994). 'Renville' is a widely grown durum cultivar in North Dakota, and 'Omega' is a yellowseeded edible flax cultivar used in the baking industry. The experimental design was a randomized complete block in a $3 \times 3$ factorial arrangement (Steel and Torrie, 1980) with three replicates. The crops were grown on soil to which three rates of $\mathrm{Zn}$ fertilizer had been added by broadcast application and incorporation with a disk. The three $\mathrm{Zn}$ treatments consisted of a control where no $\mathrm{Zn}$ was added, 5 , and $25 \mathrm{~kg} \mathrm{Zn} \mathrm{ha}^{-1}$, incorporated as described previously. Crops were sown in six rows spaced $0.31 \mathrm{~m}$. Experiment 2 had 10 environments: Fargo 94, Langdon 94, Minot (Niobell) 94, Minot (Williams) 94, Prosper 94, Fargo 95, Langdon 95, Minot (Niobell) 95, Minot (Williams) 95, and Prosper 95. Establishment and fertilization of Experiment 2 were the same as described in Experiment 1. Durum and flax seed were harvested and threshed following the same procedures described in Experiment 1.

\section{Analytical and statistical methods}

A Bartlett's test for homogeneity of variance indicated that analysis could be conducted across location-years in both experiments. Location and year were combined and termed 'environment', and considered a random effect. Crops and $\mathrm{Zn}$ rates were considered fixed effects. $-F$-protected LSD at $P \leq 0.05$ was used to evaluate differences among treatment means. The SAS system was used for the statistical analysis.

Crop available forms of $\mathrm{Cd}$ and $\mathrm{Zn}$ were determined from soil samples collected prior to seeding and $\mathrm{Zn}$ 
fertilization at each environment based on the chelating agent DPTA method of Lindsay and Norvell (1978). For this analysis a soil sample of $10 \mathrm{~g}$ was used and $\mathrm{Cd}$ was extracted with $20 \mathrm{~mL}$ of $0.05 \mathrm{mM}$ DTPA, TEA-CaCl $2, \mathrm{pH}$ 7.3 , for $2 \mathrm{~h}$. Analyses were conducted at the USDA-ARS Plant, Soil, and Nutrition Laboratory, Ithaca, New York. For Cd seed analysis, all seed or grains were digested in concentrated nitric-perchloric acid before analysis. Small grains and flax seeds were well-mixed in quantities of 1.0 or $0.25 \mathrm{~g}$, respectively, of whole seed. Seed was weighed into $25-\mathrm{mL}$ pyrex tubes for digestion on a temperaturecontrolled heating block. The samples of larger seed were ground in a stainless-steel coffee grinder and then $1.0 \mathrm{-g}$ portions of the ground sample digested. Digested seed samples were diluted to $10 \mathrm{~mL}$, and analyzed on an inductively coupled Argon Plasma Emission Spectrometer (Jarrel-Ash ICAP 61, Environmental Trace ICP Spectrometer). Analyses were conducted at the USDA-ARS Plant, Soil, and Nutrition Laboratory. Correlation was performed between soil $\mathrm{Cd}$ and seed $\mathrm{Cd}$ for each crop across environments.

\section{RESULTS AND DISCUSSION}

The natural Cd levels of the five soil series represented in the study ranged from 0.08 to $0.23 \mu \mathrm{g} \mathrm{g}^{-1}$ (Table 2). Soils generally contain between 0.01 to $30 \mu \mathrm{g} \mathrm{Cd} \mathrm{g}^{-1}$ with a typical range of 0.06 to $0.5 \mu \mathrm{g} \mathrm{Cd} \mathrm{g}^{-1}$ (Haghiri, 1974; Ryan et al., 1982; Wagner, 1993). The Fargo and Bearden/ Perella soil series were high in natural soil $\mathrm{Cd}$ content. The Niobell soil series was intermediate in soil Cd content, and the Svea and Williams soil series were relatively low in soil Cd content. In our study, the seed $\mathrm{Cd}$ accumulation of the crops was higher when the crops were grown on soils with naturally high $\mathrm{Cd}$ levels (Table 3 ). These soil series, Fargo and Bearden/Perella, originated from a lacustrine that has a distinct component of Cretaceous Pierre Shales with elevated levels of $\mathrm{Cd}$.

Simon (1998) reported that sunflower grown on soils with a $\mathrm{Cd}$ salt addition accumulated a significantly higher amount of $\mathrm{Cd}$ in the seed than sunflower grown on untreated soils, although this study was conducted on pots. These results are not comparable to the present research, and hardly relevant to farm crop Cd levels. Similar results were obtained by Hocking and McLaughlin (2000) in a flax study in Australia, where they reported that $\mathrm{Cd}$ accumulation in flax varied among different soil series depending on soil Cd level. Same results were obtained in these studies since crops grown on soil series with high $\mathrm{Cd}$ level accumulated higher levels of $\mathrm{Cd}$. These studies suggest that $\mathrm{Cd}$ content of the soil is an important factor in seed $\mathrm{Cd}$ content.

\section{Experiment 1. Crops grown with and without $\mathrm{Zn}$ fertilizer}

The combined analysis of the data across six environments and 11 crops indicated significant differences in seed $\mathrm{Cd}$ content for the main effects of crop and zinc treatment, and the environment $\times$ crop, and crop $\times \mathrm{Zn}$ interactions.

The environment $\times$ crop interaction was significant, primarily due to the magnitude of differences among environments for crops that tended to accumulate $\mathrm{Cd}$ in their seed (Table 3). These crops were durum, flax, sunflower, and soybean. For these crops, greater seed Cd occurred when grown on the soil series with high natural $\mathrm{Cd}$ content. Even among these soil series, Fargo and Bearden/Perella that occurred at the Fargo and Prosper locations, respectively, crop seed $\mathrm{Cd}$ content varied with year. Cadmium seed accumulation in soybean and sunflower was reduced at both Fargo and Prosper when comparing 1995 with 1994 (Table 3). Soybean seed Cd content was 41 and 34\% greater at Fargo and Prosper, respectively, when comparing seed Cd levels in 1994 with those in 1995. The greatest difference in seed Cd content between 1994 and 1995 occurred for sunflower where seed Cd content was approximately 50\% less in 1995 than 1994 at the Fargo location with the Fargo soil series. Sunflower seed Cd content was approximately

Table 3. Mean crop seed Cd content averaged across two Zn treatments at six North Dakota environments for Experiment 1.

\begin{tabular}{|c|c|c|c|c|c|c|c|}
\hline Crop & $\begin{array}{c}\text { Fargo } \\
1994\end{array}$ & $\begin{array}{c}\text { Prosper } \\
1994\end{array}$ & $\begin{array}{c}\text { Fargo } \\
1995\end{array}$ & $\begin{array}{c}\text { Langdon } \\
1995\end{array}$ & $\begin{array}{c}\text { Minot }(W)^{1} \\
1995\end{array}$ & $\begin{array}{c}\text { Prosper } \\
1995\end{array}$ & Mean \\
\hline & & & 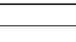 & $-\mu g g^{-1}$ & & & - \\
\hline 'Renville' durum wheat & 0.24 & 0.29 & 0.22 & 0.15 & 0.14 & 0.29 & 0.22 \\
\hline ‘Grandin' HRSW² & 0.08 & 0.07 & 0.07 & 0.04 & 0.05 & 0.04 & 0.06 \\
\hline 'Robust' barley (6-rowed) & 0.06 & 0.07 & 0.04 & 0.02 & 0.02 & 0.09 & 0.05 \\
\hline 'Stark' barley (2-rowed) & 0.04 & 0.07 & 0.03 & 0.02 & 0.02 & 0.04 & 0.04 \\
\hline 'Whitestone' oat & 0.07 & 0.05 & 0.05 & 0.01 & 0.03 & 0.03 & 0.04 \\
\hline 'Omega' flax & 1.09 & 1.25 & 1.01 & 0.49 & 0.60 & 0.96 & 0.90 \\
\hline '954' sunflower & 1.09 & 0.93 & 0.56 & 0.41 & 0.70 & 0.79 & 0.75 \\
\hline '2442' corn & 0.01 & 0.02 & 0.01 & 0.01 & 0.01 & 0.01 & 0.01 \\
\hline 'McCall' soybean & 0.49 & 0.47 & 0.29 & 0.26 & 0.21 & 0.31 & 0.34 \\
\hline 'Olathe' pinto bean & 0.04 & 0.05 & 0.02 & 0.02 & 0.03 & 0.03 & 0.03 \\
\hline 'Norstar' navy bean & 0.02 & 0.04 & 0.01 & 0.01 & 0.01 & 0.02 & 0.02 \\
\hline \multicolumn{8}{|c|}{ LSD (0.05) Environment $\times$ crop $=0.10$} \\
\hline $\operatorname{LSD}(0.05)$ Crop $=0.20$ & & & & & & & \\
\hline
\end{tabular}

${ }^{2}$ Hard red spring wheat. 
15\% less in 1995 than 1994 at the Prosper location with the Bearden/Perella soil series. Seed Cd content in flax at Fargo was similar in 1994 and 1995, but at Prosper flax seed Cd was 23\% less when comparing 1995 with 1994. Soil series and year appear to influence seed $\mathrm{Cd}$ content more for the crops that tend to accumulated seed Cd. However, durum wheat seed Cd was similar at the Fargo and Prosper environments in 1994 and 1995. The Fargo soil series is more clayey than the Bearden/ Perella series and climatic differences between years often influence treatment effects. Extended wet periods were observed in 1995 at the Prosper and Fargo locations that may have reduced soil oxygen levels and nutrient uptake. Environmental factors influence different crops and the same crop differently for seed Cd concentration even on the same soil series. Extensive wet periods can reduce chloride levels in the rooting zone, and thus lower $\mathrm{Cd}$ accumulation indirectly through effects on chloride (Liu et al., 2007). Soil drainage groups differ in extent of leaching of chloride by natural rainfall, and this drainage difference was the major factor found to influence $\mathrm{Cd}$ concentration in ND-MN sunflower kernels (Chaney et al., 1993).

Cadmium accumulating crops in our study were flax, sunflower, soybean, and durum. Mean seed Cd content of these crops across environments was $0.90,0.75,0.34$, and $0.22 \mu \mathrm{g} \mathrm{g}^{-1}$ for flax, sunflower, soybean, and durum wheat, respectively. Among the six environments evaluated, seed $\mathrm{Cd}$ content was greater for flax than sunflower at three environments; seed Cd was similar for flax and sunflower at three environments; seed Cd ranking for soybean and durum wheat was lower than for flax and sunflower at all environments; and seed $\mathrm{Cd}$ was similar for soybean and durum wheat at four of six environments and lower for durum wheat than soybean at two of six environments. Our results indicate that soybean accumulated similar or more $\mathrm{Cd}$ than durum wheat. This does not agree with $\mathrm{Li}$ et al.(1997), who reported that durum wheat accumulated greater quantities of $\mathrm{Cd}$ than soybean.

Crops that accumulated lower seed $\mathrm{Cd}$ in our study were hard red spring wheat, six-rowed barley, tworowed barley, oat, pinto bean, navy bean, and corn where mean seed Cd across environments was $0.06,0.05,0.04$, $0.04,0.03,0.02$, and $0.01 \mu \mathrm{g} \mathrm{g}^{-1}$, respectively (Table 3 ). Ranking of these crops low in accumulating seed $\mathrm{Cd}$ can be divided into three general groups based on their mean seed $\mathrm{Cd}$ level across and among environments. Among environments, maximum seed Cd levels from 0.07 to 0.09 $\mu \mathrm{g} \mathrm{g}^{-1}$ were noted for hard red spring wheat, barley, and oat. The maximum seed $\mathrm{Cd}$ levels occurred when these crops were grown on the soil series with high natural soilDTPA-Cd content. Soil series high in DTPA-Cd content elevated seed $\mathrm{Cd}$ in three of four environments for hard red spring wheat, barley, and oats. Maximum seed Cd levels from 0.04 to $0.05 \mu \mathrm{g} \mathrm{g}^{-1}$ were noted for navy and pinto bean and occurred, but not always, when these crops were grown on soil series high in natural $\mathrm{Cd}$ content. Maximum seed $\mathrm{Cd}$ levels from 0.01 to $0.02 \mu \mathrm{g} \mathrm{g}^{-1}$ were noted for corn with the one instance for maximum $\mathrm{Cd}$ occurring on a soil series high in soil-DTPA-Cd content (Table 3). The results for crops low in seed $\mathrm{Cd}$ accumulation, hard red spring wheat, barley, and oat, indicate that when these crops are grown on soil series high in DTPA-Cd content that they are likely to have elevated seed Cd compared to when grown on soils with low Cd content. Navy and pinto bean and especially corn had less association between seed $\mathrm{Cd}$ and soil series $\mathrm{Cd}$ content.

These results agree with those of Chaney et al. (1993), who reported that sunflower and flax accumulated higher Cd levels than most other grains. These authors also suggested that sunflower kernel $\mathrm{Cd}$ did increase with increasing soil-DTPA-Cd even though they felt genotype variation exceeded the soil-DTPA-effect. Correlation between seed and soil $\mathrm{Cd}$ content in our study suggests that soil $\mathrm{Cd}$ level in addition to crop genetics is important in seed $\mathrm{Cd}$ content. Correlation coefficients between seed and soil Cd were 0.83, 0.50, 0.69, and 0.69 for flax, sunflower, soybean, and durum, respectively (data not shown) and indicate seed $\mathrm{Cd}$ content for these crops tended to increase as soil $\mathrm{Cd}$ content increased. A limit of $0.6 \mathrm{mg} \mathrm{kg}^{-1} \mathrm{Cd}$ fresh weight concentration for imported non-oilseed sunflower kernels was established by Germany in 1992. Based on these limits, obtaining sunflower hybrids that accumulate less that $0.6 \mathrm{mg} \mathrm{kg}^{-1}$ of $\mathrm{Cd}$ in their kernels is important for marketability (Chaney et al., 1993). Shipments to Germany (but not all of the EU nations) could be as much as two-fold the limit before crop importation was rejected. But individual purchasers could reject the shipment at the $0.6 \mathrm{mg} \mathrm{kg}^{-1}$ level. Flax was originally limited to $0.3 \mathrm{mg} \mathrm{kg}^{-1} \mathrm{Cd}$, but by the late $1990 \mathrm{~s}$, this was raised to match the $0.6 \mathrm{mg} \mathrm{kg}^{-1}$ allowed for sunflower kernels. Hammond et al. (1999) found some flax genotypes with $\mathrm{Cd}$ levels over $3 \mathrm{mg} \mathrm{kg}^{-1} \mathrm{Cd}$ when grown on Fargo silty clay loam soil and such kernels cannot be exported to Europe.

Previous researchers (Oliver et al., 1994) reported Zn fertilizer additions can reduce seed $\mathrm{Cd}$ concentration when soil DTPA-extractable $\mathrm{Zn}$ levels are initially deficient. In our study the crop by $\mathrm{Zn}$ interaction was significant and indicated addition of $\mathrm{Zn}$ fertilizer had no effect on $\mathrm{Cd}$ accumulation for the crops previously identified as being low in seed Cd concentration. However, for flax, a crop associated with seed $\mathrm{Cd}$ concentration, addition of $\mathrm{Zn}$ fertilizer caused lower seed $\mathrm{Cd}$ concentration (Table 4). Lack of a reduced seed Cd response for the other $\mathrm{Cd}$ accumulating crops sunflower, soybean, and durum, with $\mathrm{Zn}$ fertilizer addition is unclear, but may be related to the relatively high initial soil $\mathrm{Zn}$ levels for the different soil series (Table 2). Three of the five soil series showed DTPA-extractable Zn levels (Table 2) above the normal 
Table 4. Mean crop seed $\mathrm{Cd}$ content for two $\mathrm{Zn}$ treatments averaged across six North Dakota environments for Experiment 1.

\begin{tabular}{lcc}
\hline & \multicolumn{2}{c}{ Seed Cd content } \\
\cline { 2 - 3 } Crop & No Zn & $\mathrm{Zn}$ \\
\cline { 2 - 3 } 'Renville' durum wheat & 0.22 & 0.21 \\
'Grandin' HRSW & 0.06 & 0.06 \\
'Robust' barley (6-rowed) & 0.05 & 0.05 \\
'Stark' barley (2-rowed) & 0.03 & 0.03 \\
'Whitestone' oat & 0.04 & 0.04 \\
'Omega' flax & 1.00 & 0.87 \\
'954' sunflower & 0.76 & 0.73 \\
'2442' corn & 0.01 & 0.01 \\
'McCall' soybean & 0.34 & 0.33 \\
'Olathe' pinto bean & 0.03 & 0.03 \\
'Norstar' navy bean & 0.02 & 0.02 \\
Mean & 0.22 & 0.21 \\
LSD (0.05) Crop $\times$ Zn $=0.03$ & & \\
\hline HRSW = hard red spring wheat. & &
\end{tabular}

range of 0.51 to $0.75 \mu \mathrm{g} \mathrm{g}^{-1}$ stated by Franzen (2003). The other soil series, Williams and Bearden/Perella, DTPAextractable Zn levels (0.62 and $0.6 \mu \mathrm{g} \mathrm{g}{ }^{-1}$, respectively, Table 2) would be within the normal range as stated by Franzen (2003). Since soil DTPA-extractable Zn levels were already high for the soil series, further $\mathrm{Zn}$ additions may have been ineffective in lowering seed $\mathrm{Cd}$ content. Harris and Taylor (2001) reported that Cd accumulation may be reduced in seeds when $\mathrm{Zn}$ fertilizer additions remove $\mathrm{Zn}$ stress on plants. Crops in our study were likely not subject to $\mathrm{Zn}$ stress. Crop seed Cd ranking is similar for the non- $\mathrm{Zn}$ and $25-\mathrm{kg} \mathrm{ha}^{-1}-\mathrm{Zn}$ fertility treatments. The crop by $\mathrm{Zn}$ interaction is primarily caused by reduced seed $\mathrm{Cd}$ level at the high $\mathrm{Zn}$ fertility treatment for flax. Sunflower seed Cd level was also statistically less at the high $\mathrm{Zn}$ fertility treatment $\left(0.73 \mu \mathrm{g} \mathrm{g}^{-1}\right)$ compared with the non- $\mathrm{Zn}$ treatment $\left(0.76 \mu \mathrm{g} \mathrm{g}^{-1}\right)$, but the biological importance of this difference is minimal. Also, chloride levels, known to be a significant factor in crop $\mathrm{Cd}$ concentration, may have played a role on the $\mathrm{Zn}$ effect on Cd concentration in the seed.

\section{Experiment 2. Flax and durum wheat cultivars with and without $\mathbf{Z n}$ fertilizer}

The combined analysis across 10 environments indicated the main effects of crop and $\mathrm{Zn}$ treatment and the environment $\times$ crop, and crop $\times \mathrm{Zn}$ interactions were significant for seed $\mathrm{Cd}$ content (Tables 5 and 6). The crop $\times \mathrm{Zn}$ interaction occurred primarily because the $\mathrm{Cd}$ accumulation in flax was three to four times greater than the $\mathrm{Cd}$ accumulation in either durum wheat cultivar (Table 5). This agrees with Grant and Bailey (1997), who found that flax tends to accumulate higher seed $\mathrm{Cd}$ than cereal crops. Medora durum wheat seed Cd content showed no response to $\mathrm{Zn}$ fertilization, however, Renville durum wheat showed reduced seed $\mathrm{Cd}$ content at the 25 $\mathrm{kg} \mathrm{ha}^{-1} \mathrm{Zn}$ rate compared to the control and $5 \mathrm{~kg} \mathrm{ha}^{-1} \mathrm{Zn}$ rate. Williams and David (1976) and Abdel-Sabour et al. (1988) reported synergistic and antagonist effects of soil applied $\mathrm{Zn}$ fertilizer on seed $\mathrm{Cd}$ content. A significant $\mathrm{Cd}$ reduction with $\mathrm{Zn}$ fertilization has been reported for soils which tested $\mathrm{Zn}$ deficient according to soil tests such as the DTPA method. Zinc fertilization on Zn-deficient soils reduced seed Cd concentration (Oliver et al., 1994; Grant and Bailey, 1997). Seed Cd content was unique at each $\mathrm{Zn}$ rate for flax with values decreasing as $\mathrm{Zn}$ rate increased. The reduction in the flax seed $\mathrm{Cd}$ content was $13 \%$ at the $25 \mathrm{~kg} \mathrm{ha}^{-1} \mathrm{Zn}$ rate compared with the control. This is in general agreement with our results in Experiment 1 where flax seed Cd content was $10 \%$ less at the $25 \mathrm{~kg} \mathrm{Zn} \mathrm{ha}^{-1}$ rate compared with the control.

The environment $\times$ crop interaction indicated ranking differences among environments for crop seed $\mathrm{Cd}$ content (Table 6). Flax concentrated the highest amount of seed $\mathrm{Cd}$ at each environment where soil parent material produced high soil $\mathrm{Cd}$ content. These environments were at Fargo and Prosper, where the soil series were Fargo and Bearden/Perella, respectively. At these environments, flax seed $\mathrm{Cd}$ ranged from 0.79 to $1.12 \mu \mathrm{g} \mathrm{g} \mathrm{g}^{-1}$. At the environments where soils were lower in $\mathrm{Cd}$ content, flax seed Cd content ranged from 0.40 to $0.51 \mu \mathrm{g} \mathrm{g} \mathrm{g}^{-1}$.

Seed Cd content for the durum cultivars ranged from 0.16 to $0.32 \mu \mathrm{g} \mathrm{g}^{-1}$ at the environments where soil $\mathrm{Cd}$ levels were naturally high (Table 6). At the Langdon environments where soil $\mathrm{Cd}$ was low, durum seed $\mathrm{Cd}$ content ranged from 0.12 to $0.15 \mu \mathrm{g} \mathrm{g} \mathrm{g}^{-1}$. At the Minot location the Williams soil series durum seed $\mathrm{Cd}$ was relatively low in 1995 (0.08 to $0.09 \mu \mathrm{g} \mathrm{g}^{-1}$ ), but was considerably higher in $1994\left(0.22 \mu \mathrm{g} \mathrm{g}^{-1}\right)$. This again illustrates the influence on seed $\mathrm{Cd}$ level by variable growing season conditions when crops are grown on the same soil series. The environment $\times$ crop interaction was largely caused by ranking differences between the durum cultivars among the environments. At eight of the 10 environments, both durum cultivars accumulated similar seed $\mathrm{Cd}$, but at two of the environments greater seed Cd content was observed for 'Medora' than 'Renville'. This supports but does not strongly agree with Choudhary et al. (1994) and Jalil et al. (1994), who suggested that Medora is a higher accumulator of seed Cd than Renville.

Table 5. Mean crop seed Cd content of two durum wheats and one flax cultivar at three $\mathrm{Zn}$ treatments averaged across 10 North Dakota environments for Experiment 2.

\begin{tabular}{lcc}
\hline Crop & Zinc rate & Seed Cd content \\
\hline & $\mathrm{kg} \mathrm{ha}^{-1}$ & $\mu \mathrm{g} \mathrm{g}^{-1}$ \\
'Renville' durum wheat & Control & 0.18 \\
'Renville' durum wheat & 5 & 0.19 \\
'Renville' durum wheat & 25 & 0.15 \\
'Medora' durum wheat & Control & 0.16 \\
'Medora' durum wheat & 5 & 0.16 \\
'Medora' durum wheat & 25 & 0.16 \\
'Omega' flax & Control & 0.72 \\
'Omega' flax & 5 & 0.69 \\
'Omega' flax & 25 & 0.65 \\
LSD (0.05) Crop $\times \mathrm{Zn}=0.03$ & &
\end{tabular}


Table 6. Mean crop seed Cd content of two durum and one flax cultivar at $\mathbf{1 0}$ North Dakota environments averaged across three Zn treatments for Experiment 2.

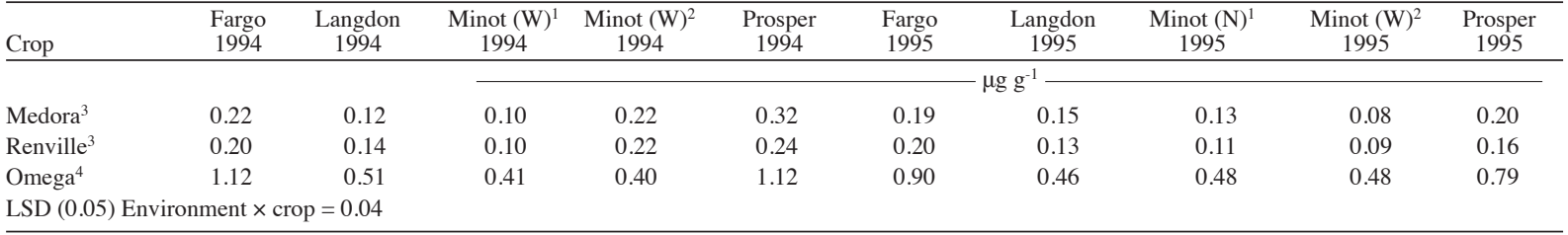

${ }^{1}$ Minot soil series Niobell.

${ }^{2}$ Minot soils series Williams.

${ }^{3}$ Durum.

${ }^{4}$ Flax

\section{CONCLUSIONS}

The addition of $\mathrm{Zn}$ fertilizer did not have a consistent effect on seed $\mathrm{Cd}$ content for the crops and soils evaluated in our study. Therefore, $\mathrm{Zn}$ fertilization is not a practical means to reduce seed $\mathrm{Cd}$ content and hence other agronomic practices, especially plant breeding, need to be implemented to produce cultivars that accumulate low levels of $\mathrm{Cd}$. In order to reduce seed $\mathrm{Cd}$ content, producers should grow sensitive crops on soil series with properties that promote low seed $\mathrm{Cd}$ accumulation. Based on the results of these studies, crops that tend to accumulate seed $\mathrm{Cd}$ could be grown on soil series Niobell, Williams, and Svea since these soils have low natural levels of $\mathrm{Cd}$. Therefore, matching crops with the proper soil series seems to be the best management practice to produce seed with Cd levels acceptable to the Codex Alimentarius Commission.

Flax, non-oilseed sunflower, soybean, and durum wheat were the greatest accumulators of seed Cd among the tested crops. Among these four crops, flax and nonoil sunflower accumulated higher seed $\mathrm{Cd}$ than soybean or durum wheat. Soybean and durum wheat tended to have similar seed $\mathrm{Cd}$ content, but soybean seed $\mathrm{Cd}$ content was approximately twice as high as durum at two environments where soils had naturally high $\mathrm{Cd}$ levels. This indicates that the growing-season conditions had an effect on soybean seed Cd content. This is likely related to many of the previous $\mathrm{Cd}$ studies pertaining to seed $\mathrm{Cd}$ accumulation being conducted under controlled greenhouse and not field conditions.

\section{ACKNOWLEDGEMENTS}

North Dakota Agricultural Research Stations for providing the funding that made this study possible. All the members of the New Crop Project at North Dakota State University for their collaboration on this study.

Efecto de la fertilización con zinc en la acumulación de cadmio en semillas oleaginosas y cereales producidos en suelos de Dakota del Norte. La concentración de $\mathrm{Cd}$ en semillas depende de varios factores, tanto del suelo como de la planta. Cadmio y $\mathrm{Zn}$ pueden tener efectos antagónicos o sinérgicos en la absorción de la planta dependiendo de las concentraciones de $\mathrm{Cd}$ y Zn existentes en el suelo. El objetivo de este estudio fue determinar el efecto de la fertilización con $\mathrm{Zn}$ en la acumulación de $\mathrm{Cd}$ en la semilla de diversos cultivos comúnmente producidos en Dakota del Norte, EE.UU. Dos estudios fueron realizados en cinco localidades en Dakota del Norte que representaban diferentes series de suelo durante 1994 y 1995. Experimento 1, nueve cultivos fueron evaluados con y sin la adición de $25 \mathrm{~kg} \mathrm{Zn} \mathrm{ha}^{-1}$. Entre los cultivos evaluados, la acumulación más alta de $\mathrm{Cd}$ en las semillas ocurrió en lino (Linum usitatissimum L.) seguido por girasol (Helianthus annuus L.), soya (Glycine max [L.] Merr.), y trigo duro (Triticum turgidum L. var. durum). Experimento 2, dos cultivares de trigo duro y un cultivar de lino fueron evaluados bajo tres tratamientos de fertilización, 0 , 5, y $25 \mathrm{~kg} \mathrm{Zn} \mathrm{ha}^{-1}$. En este estudio nuevamente la acumulación de $\mathrm{Cd}$ fue más alta en lino. De acuerdo con los resultados de ambos estudios, la adición de $\mathrm{Zn}$ no produjo una disminución constante del contenido $\mathrm{Cd}$ en las semillas, incluso cuando existían diferencias significativas el nivel de reducción fue bajo, lo cual probablemente no afectaría la comerciabilidad de cultivos como lino, girasol, soya, y trigo duro.

Palabras clave: series de suelos, semillas, absorción, nutrientes, contaminación, Linum usitatissimum, Triticum turgidum.

\section{LITERATURE CITED}

Abdel-Sabour, M., J. Mortvedt, and J. Kelose. 1988. Cadmium-zinc interaction in plants and extractable cadmium and zinc fractions in soil. Soil Science 145:424-431.

Alloway, B.J. 1995. Cadmium. p. 122-151. In B.J. Alloway (ed.) Heavy metals in soils. Blackie Academic \& Professional, London, UK.

Bingham, F.T. 1979. Bioavailability of Cd to food crops in relation to heavy metal content of sludge-amended soil. Environment Health Perspective 28:39-43.

Brennan, R.F., and M.D.A. Bolland. 2004. Wheat and canola response to concentrations of phosphorus and cadmium in a sandy soil. Australian Journal of Experimental Agriculture 44:10251029.

Brennan, R.F., and R.J. French. 2005. Grain yield and cadmium concentration of a range of grain legume species grown on two soil types at Merredin, Western. Australian Journal of Experimental Agriculture 45:1167-1172.

Carrier, P., A. Baryla, and M. Havaux. 2003. Cadmium distribution and microlocalization in oilseed rape (Brassica napus) after longterm growth on cadmium-contaminated soils. Planta 216:939-950. 
Chaney, R., L.M. Li, A. Schneiter, C.E. Green, J.F. Miller, and D. Hopkins. 1993. Progress in developing technologies to produce low cadmium concentration sunflower kernel. p. 8092. In Proceeding of the $15^{\text {th }}$ Sunflower Research Workshop, Fargo, North Dakota. 14-15 January 1993. National Sunflower Association, Bismarck, North Dakota, USA.

Chen, F., F. Wu, J. Dong, E. Vincze, G. Zhang, F. Wang, et al. 2007. Cadmium translocation and accumulation in developing barley grains. Planta Online doi:10.1007/s00425-007-0610-3.

Choudhary, M., L. Bailey, and C. Grant. 1994. Effect of zinc on cadmium concentration in the tissue of durum wheat. Canadian Journal of Plant Sciences 74:549-552.

Codex Alimentarius Commission. 2000. Report of the thirtysecond session of the Codex Committee of Food Additives and Contaminants. Joint FAO/WHO Food Standards Program. 20-24 March 2000. Beijing, People's Republic of China.

Davis, R.D. 1984. Cadmium in sludges used as fertilizers. Experientia 40:117-126.

Franzen, D.W. 2003. North Dakota fertilizer recommendation tables and equations based on soils test levels and yield goals. Extension Bulletin SF-882. North Dakota State University, Extension Service, Fargo, North Dakota, USA.

Gerritse, R.G., W. Van Driel, K.W. Smilde, and B. Van Luit. 1983. Uptake of heavy metals by crops in relations to their concentration in the soil solution. Plant and Soil 75:393-404.

Grant, C.A., and L.D. Bailey. 1997. Effects of phosphorus and zinc fertilizer management on cadmium accumulation in flaxseed Journal of Science-Food and Agriculture 73:307-314.

Haghiri, F. 1973. Cadmium uptake by plants. Journal of Environmental Quality 2:93-95.

Haghiri, F. 1974. Plant uptake of cadmium as influenced by cation exchange capacity, organic matter, zinc, and soil temperature. Journal of Environmental Quality 3:180-182.

Hammond, J.J., J.F. Miller, C.E. Green, and R.L. Chaney. 1999 Screening the USDA flax collection for seed cadmium. p. 7778. In ASA-CSA-CSAA Annual Meetings. Agronomy Abstracts 1999:77-78.

Harris, N.S., and G.J. Taylor. 2001. Remobilization of cadmium in maturing shoots of near isogenic lines of durum wheat that differ in grain cadmium accumulation. Journal of Experimental Botany 52(360):1473-1481

Hocking, P.J., and M.J. McLaughlin. 2000. Genotypic variation in cadmium accumulation by seed of linseed, and comparison with seeds of other crop species. Australian Journal of Agricultural Research 51:427-433.

Howey, R.L. 1974. Soil survey of Ward County, North Dakota. USDA Soil Conservation Service in cooperation with North Dakota Agricultural Experiment Station and North Dakota Soil Conservation Committee, Washington, D.C., USA

Jalil, A., F. Selles, and J.M. Clarke. 1994. Growth and cadmium accumulation in two durum wheat cultivars. Communications in Soil Science and Plant Analysis 25:2597-2611.

Jarvis, S.C., L.H.P. Jones, and M.J. Hopper. 1976. Cadmium uptake from solution by plants and its transport from roots to shoots. Plant and Soil 44:179-191.

John, M.K. 1973. Cadmium uptake by eight food crops as influenced by various soil levels of cadmium. Environmental Pollution 4:715.

Kuboi, T., A. Noguchi, and J. Yazaki. 1987. Relationship between tolerance and accumulation characteristics of cadmium in higher plants. Plant and Soil 104:275-280.

Lagerwerff, J.V. 1971. Uptake of cadmium, lead, and zinc by radish from soil and air. Soil Science 111:129-133.

Li, Y.M., R.L. Chaney, A.A. Schneiter, J.F. Miller, E.M. Elias, and J.J. Hammond. 1997. Screening for low cadmium phenotypes in sunflower, durum wheat and flax. Euphytica 94:23-30.
Lindsay, W.L., and W.A. Norvell. 1978. Development of a DTPA soil test for zinc, iron, manganese and copper. Soil Science Society of American Journal 42:421-428.

Liu, Q., A. Tjoa, and V. Römheld. 2007. Effects of chloride and co-contaminated zinc on cadmium accumulation within Thlaspi caerulescens and durum wheat. Bulletin of Environment Contamination and Toxicology 79:62-65.

Makino, T., K. Sugahara, Y. Sakurai, H. Takano, T. Kamiya, K Sasaki, et al. 2006. Remediation of cadmium contamination in paddy soils by washing with chemicals: Selection of washing chemicals. Environmental Pollution 144:2-10.

McLaughlin, M.J., C.M.J. Williams, A. McKay, R. Kirkham, J. Gunton, K.J. Jackson, R. Thompson, et al. 1994. Effect of cultivar on uptake of cadmium by potato tubers. Australian Journal of Agricultural Research 45:1483-1495.

Moustakas, N.K., A. Akoumianaki-Ioannidou, and P.E. Barouchas. 2011. The effects of cadmium and zinc interactions on the concentration of cadmium and zinc in pot marigold (Calendula officinalis L.). Australian Journal of Crop Sciences 5:277-282.

Norvell, W.A., J. Wu, D.G. Hopkins, and R.M. Welch. 2000 Association of cadmium in durum wheat grain with soil chloride and chelate-extractable soil cadmium. Soil Science Society of American Journal 64:2162-2168.

Oliver, D.P., R. Hannam, K.G. Tiller, N.S. Wilhelm, R.H. Merry, and G.D. Cozens. 1994. Heavy metals in the environment: The effect of zinc fertilization on cadmium concentration in wheat grain Journal of Environmental Quality 23:705-711.

Ryan, J., H. Pahren, and J. Lucas. 1982. Controlling cadmium in the human food chain: Review and rationale based on the health effect. Environmental Research 28:251-302.

Schultz, L.G., H.A. Tourtelot, and J.R. Gill. 1980. Composition and properties of the Pierre Shale and equivalent rocks, Northern Great Plains Region. Geological Survey, United States Government, Washington, D.C., USA.

Simmons, M. 1990. Soil survey of Cavalier county, North Dakota. USDA Soil Conservation Service in cooperation with North Dakota Agricultural Experiment Station and North Dakota Soil Conservation Committee, Washington, D.C., USA.

Simon, L. 1998. Cadmium accumulation and distribution in sunflower plant. Journal of Plant Nutrition 21:341-352.

Soil Survey Division. 2001. Natural Resources Conservation Service, United States Department of Agriculture. Official Soil Series Descriptions [Online]. Available at http://soils.usda.gov/ technical/classification/osd/index.html (accessed 25 November 2011).

Steel, R.G., and J.H. Torrie. 1980. Principles and procedures of statistics - A biometrical approach. $2^{\text {nd }}$ ed. McGraw-Hill Book, New York, USA.

USDA Soil Conservation Service. 1985. Soil survey of Cass County Area North Dakota. USDA Soil Conservation Service in cooperation with North Dakota Agricultural Experiment Station and North Dakota Soil Conservation Committee, Washington, D.C., USA.

Wagner, G. 1993. Accumulation of cadmium in crop plants and its consequences to human health. Advances in Agronomy 51:173212.

Williams, C., and D. David. 1976. The accumulation in soil of cadmium residues from phosphate fertilizer and their effect on the cadmium content of plants. Soil Science 121:86-93.

Wu, J., W.A. Norvell, D.G. Hopkins, and R.M. Welch. 2002. Spatial variability of grain cadmium and soil characteristics in a durum wheat field. Soil Science Society of America Journal 66:268-275. 